\title{
Bacteriophage Biocontrol of Acidovorax citrulli, the Causal Agent of Bacterial Fruit Blotch ${ }^{\dagger}$
}

\author{
Aryan Rahimi-Midani and Tae-Jin Choi * \\ Department of Microbiology, Pukyong National University, Busan 48513, Korea; \\ aryan_rahimi2011@yahoo.com \\ * Correspondence: choitj@pknu.ac.kr \\ † Presented at Viruses 2020-Novel Concepts in Virology, Barcelona, Spain, 5-7 February 2020. \\ Published: 3 June 2020
}

\begin{abstract}
Bacterial fruit blotch caused by Acidovorax citrulli is known to be the major threat to cucurbit crop production worldwide. The pathogen can penetrate into seed coat and cause disease symptoms at any stage of plant growth, which results in fruit loss. Two main genotypes (genotype I and II) are reported in A. citrulli, in which genotype II is the main cause of Bacterial Fruit Blotch (BFB) in watermelon and group I is known to be a causal agent of BFB in melon. To date, there are no commercially available cultivars resistant to $\mathrm{BFB}$, and available strategies are not able to completely manage the disease. In this study, we aim to isolate bacteriophages to control BFB. Samples collected from watermelon, melon, and pumpkin were used to isolate bacteriophages. All isolated bacteriophages were tested against 42 strains of $A$. citrulli, among which two phages with the ability to lyse a greater number of hosts were selected and characterized. Bacteriophage ACP17 from the Myoviridae family, with a head size of $100 \pm 5 \mathrm{~nm}$ and tail of $150 \pm 5 \mathrm{~nm}$, infected 29 strains of $A$. citrulli mostly belonging to genotype group $\mathrm{I}$, whereas the second isolated bacteriophage, ACPWH from Siphoviridae, with a head size of $60 \pm 5 \mathrm{~nm}$ and tail of $180 \pm 5 \mathrm{~nm}$, infected $39 \mathrm{~A}$. citrulli strains. Genome analysis of both bacteriophages using Next generation Sequencing (NGS) showed that ACP17 and ACPWH have double-stranded DNA with sizes of 156,972 kb and 424,299 $\mathrm{kb}$, respectively. Watermelon seeds coated with ACPWH showed a germination rate of up to $90 \%$ in the presence of $A$. citrulli in contrast to untreated seed, which showed no germination or germinated juveniles with BFB symptoms in the presence of $A$. citrulli. The results of this study show that the use of bacteriophages of $A$. citrulli represents a potential biocontrol method for controlling BFB.
\end{abstract}

Keywords: Bacterial fruit blotch; Acidovorax citrulli; phage biocontrol; seed coating

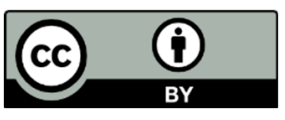

(C) 2020 by the authors. Licensee MDPI, Basel, Switzerland. This article is an open access article distributed under the terms and conditions of the Creative Commons Attribution (CC BY) license (http://creativecommons.org/licenses/by/4.0/). 